\title{
Riñón en esponja
}

\author{
Sponge kidney disease
}

Juan Miyahira ${ }^{1, a ;}$.
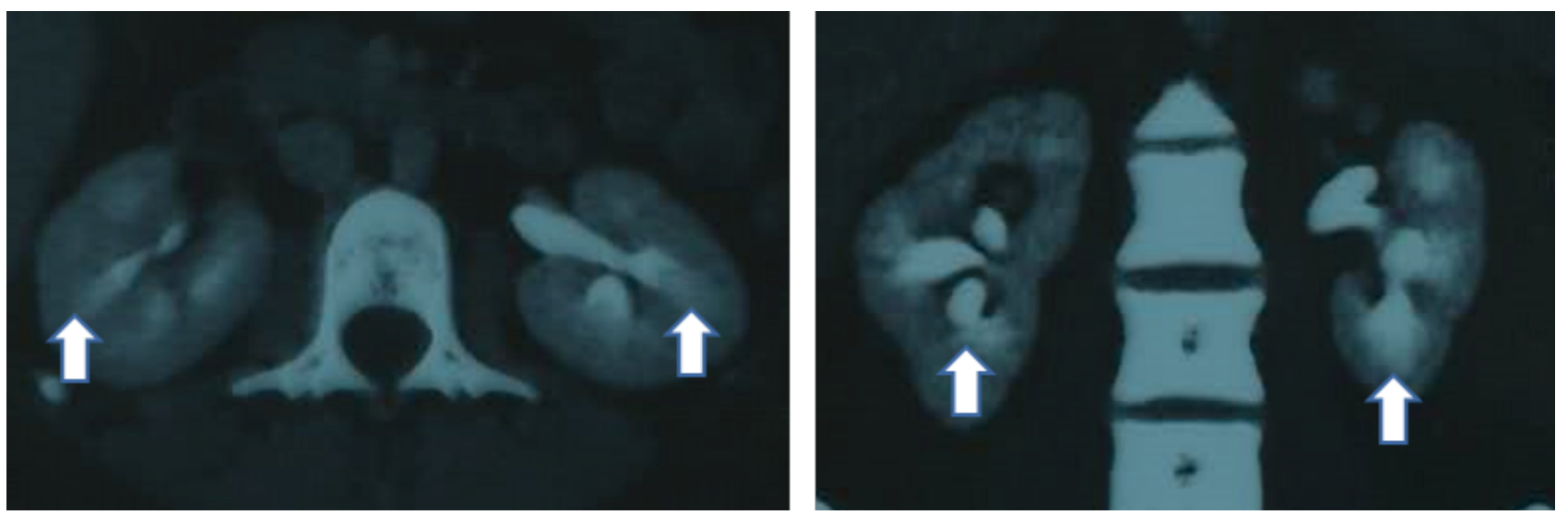

Mujer de 29 años de edad, de nacionalidad chilena, quien acudió a consulta con historia de litiasis renal recurrente. La tomografía espiral multicorte (TEM) mostró las imágenes en "barba de maíz" sobre los cálices renales, característicos de Riñón en esponja. Si bien el nombre está relacionado con la estructura anatómica, el diagnóstico es radiológico (por imágenes). Es una enfermedad rara, congénita, no hereditaria caracterizada por dilatación de los tubos colectores a nivel de las papilas renales, por esta razón se forma la imagen en "barba de maíz". La enfermedad puede ser asintomática o manifestarse como hematuria microscópica, infección urinaria, litiasis renal o nefrocalcinosis medular. Se le conoce también como enfermedad de Cachi-Ricci en honor a quienes la describieron por primera vez o ectasia tubular precalicilar.

A 29-year-old Chilean female patient attended outpatient clinic with a history of recurrent kidney stones. A CT scan showed paint-brush images characteristic of sponge kidney disease. Sponge kidney disease is a rare congenital non-hereditary condition characterized by dilation of the collecting tubules at the renal medulla giving the aspect of paint-brush. Patients may be asymptomatic or complain of microscopic hematuria, urinary tract infection, kidney stones or medullary calcinosis. The diagnosis of this condition is made on radiologic basis. It is also known as Cachi-Ricci's disease to honor the first ones who report it, but it is also known as precalicial tubular ectasis. 